\title{
Shedding Light on the Tunnel and Light in Near-Death Experiences: A Case Study
}

\author{
Janice Miner Holden, EdD, and Saharnaz Loseu, MS \\ University of North Texas
}

\begin{abstract}
Since 1975 when Raymond Moody published his influential work on near-death experiences (NDEs), controversy has existed among researchers regarding the nature and source of these phenomena. Some researchers have attributed various NDE features to physiological changes in the human body; one such feature that many experiencers have reported is rapid movement through a tunnel toward a light, which materialists have reduced to anoxic narrowing of the visual field. Although experiencers themselves and some researchers have disagreed with materialist, reductionist explanations, limited evidence has existed to contribute to a resolution of the dispute. In this article, we present a case study of an adult male who experienced both gravity induced loss of consciousness (G-LOC) as a Korean War aviation cadet, including narrowing of his visual field to a point of light, and also two subsequent transpersonal experiences-a near-death experience (NDE) and an after-death communication (ADC) - that both included a tunnel-and-light feature. His Near-Death Experience Scale scores for each experience and his comparison of the qualia of these experiences provide unique evidence in the debate about the nature and likely origins of such experiences. These data place more weight on the argument that the tunnel and light in transpersonal experiences cannot reasonably be attributed to loss of oxygen in the brain.
\end{abstract}

KEY WORDS: near-death experience, after-death communication, gravitationinduced loss of consciousness (G-LOC), hypoxia, anoxia

Since Raymond Moody coined the term near-death experience (NDE) in 1975, controversy has existed among experts in the field of near-

Janice Miner Holden, EdD, LPC-S, LMFT, NCC, ACMHP, is professor of counseling and chair of the Department of Counseling and Higher Education at the University of North Texas, Denton, TX. Her primary research interest is the transpersonal perspective in counseling with particular attention to near-death experiences.

Saharnaz Loseu, MS, LPC-Intern, is a doctoral student in the Counseling Program at the University of North Texas. Correspondence concerning this article should be addressed to Dr. Holden at jan.holden@unt.edu. 
death studies regarding the phenomena of NDEs. In 2009, the authors of The Handbook of Near-Death Experiences: Thirty Years of Investigation summarized research on numerous NDE accounts (Holden, Greyson, \& James, 2009) in which some near-death experiencers (NDErs) reported their consciousness having left their bodies, entered a tunnel, encountered an unearthly bright light, and experienced a life review (Zingrone \& Alvarado, 2009). That NDErs report these phenomena is not in dispute. However, the source and nature of the phenomena have been topics of ongoing debate between, on the one hand, materialist, reductionist theorists and researchers who have attributed the phenomena to purely physical mechanisms and, on the other hand, most NDErs themselves and other theorists and researchers who have found reductionist explanations to be inadequate to explain these phenomena (Greyson, Kelly, \& Kelly, 2009; Kelly, Kelly, Crabtree, Gauld, Grosso, \& Greyson, 2007).

Among the early representatives of the materialist, reductionist perspective were those who attributed the features of NDEs to syncope (Lempert, Bauer, \& Schmidt, 1994). According to the American Heart Association (2014),

Syncope is temporary loss of consciousness and posture, described as "fainting" or "passing out." It's usually related to temporary insufficient blood flow to the brain. It most often occurs when the blood pressure is too low (hypotension) and the heart doesn't pump a normal supply of oxygen to the brain.

Other authors similarly attributed NDEs to carbon dioxide retention, hypoxia-reduced oxygen to the brain, or anoxia-complete absence of oxygen in the brain (Agrillo, 2011; Blackmore, 1996). In particular, they drew parallels between ecstatic feelings in NDEs and euphoric feelings associated with reduced brain oxygen, such as in highaltitude-induced hypoxia (Federal Aviation Administration, 2004; Whinnery, 1997, p. 255). They also drew parallels between the NDE perception of moving rapidly through a tunnel toward a light and the anoxic experience of tunnel vision.

An early proponent of this perspective was British psychophysiologist Susan Blackmore (1996). In the 2002 British Broadcasting Corporation documentary, The Day I Died: The Mind, the Brain, and NearDeath Experiences, Blackmore explained:

The tunnel, for example, seems very clear how and why you get these dark tunnels with the bright light at the end. We know how the cells in the visual system are laid out. Right from the retina and the back 
of the eye, right the way through the visual system to the visual cortex at the back of your brain here [pointing], there are lots of cells devoted to the middle of the visual field-what you are looking at-and very few devoted towards the outside. Now, what happens when you get into shock, when you have lack of oxygen, is all the cells start firing randomly. Now, what's that going to look like? With lots of cells devoted towards the middle and very few towards the outside, it's going to look like bright light in the middle, dark towards the outside. Now, you are nearly unconscious with your eyes shut, and this is all you can see, so it feels like going forwards into, through a tunnel into a bright light. (Broome, 2002; Taka, 2010)

She went on to refer also to the link between lack of oxygen in the brain and euphoria:

Another thing that we understand pretty well is the emotional effects, because under stress and with shock and lack of oxygen, you get a massive flood of endorphins, the brain's own morphine-like chemicals, which has the effect of taking away pain, making you feel everything is absolutely fine and how it should be, giving you a very positive attitude towards everything. So that when all this stuff's coming up"Oh, there's my body dying-well, that's fine"; um, "Wow, here are these amazing things-it's all fine." So the whole experience can be colored by that particular chemical. (Broome, 2002; Taka, 2010)

Physician James Whinnery (1997), who specialized in aerospace medicine and became chief of the Brooks Air Force Base acceleration effects laboratory in San Antonio, Texas (Wright, 2008), examined the physiological correlates of NDE and gravity-induced loss of consciousness (G-LOC) that aircraft pilots experience during high acceleration $(+\mathrm{Gz})$. He reported that during $+\mathrm{Gz}$ exposure, individuals lose peripheral vision, and with higher levels of $+\mathrm{Gz}$, "visual field contracts to produce what is known as tunnel vision" (Whinnery, 1997, p. 238). He further explained that because tunnel vision is pilots' last visual memory before losing consciousness and their first memory after regaining consciousness, they experience "coming out of the darkness of a tunnel or perhaps bright sunlight" (p. 239). Whinnery noted that any physiological process, such as exposure to $+\mathrm{Gz}$ or cardiac asystole, that results in reduced perfusion of oxygen in the nervous system can produce visual symptoms of tunnel vision.

Although similarities exist between the sensation of a tunnel and light in an NDE and that resulting from oxygen deprivation, one cannot determine with certainty that they are identical because evidence is based on the subjective reports of two distinct groups of individuals: one group with NDEs and another group with G-LOC experiences. 
To our knowledge, no cases or studies have involved participants who had experienced both phenomena. To bridge this gap, we present a case study of an individual in a unique position to compare, having experienced tunnel-and-light phenomena with G-LOC during his flight experience as a Korean War aviation cadet and during two subsequent transpersonal experiences later in life: an NDE and an after-death communication (ADC).

\section{Method}

The subject of this case study was Howard Smith, EdD, whom coauthor Holden met at a College of Education social function at the University of North Texas (UNT). Knowing Holden's research on NDEs, Smith shared with her his experiences of NDE and ADC. In discussing the circumstances of his NDE, he mentioned that the only other time he had come close to losing consciousness was during G-LOC as a Korean War aviation cadet. Holden noted that all three experiences had included a tunnel-and-light feature and asked Smith if he would be willing to be recorded in an interview describing and comparing the experiences and to complete the Near-Death Experience Scale (NDE Scale; Greyson, 1983) on his NDE. He agreed, eventually also completing the NDE Scale with reference to his G-LOC and ADC experiences and signing a release for his identity, interview, and other data to be used for educational and research purposes. The result of consultation with the University of North Texas Institutional Review Board for the Use of Human Subjects was that a case study such as this, with a signed release and voluntary participation in an on-camera interview, was exempt from review.

Smith was a Caucasian male who, at the time of the interview, was 77 years old. He began his career as a teacher, completed a doctor of education degree in elementary education, and became a UNT professor who, over the course of 36 years, eventually mentored and hooded more than 100 doctoral students. During his tenure at UNT, he served not only as professor in the Higher Education Program but also as associate dean, interim dean, and acting dean of the College of Education and as associate vice president for academic affairs, vice president for academic affairs, and interim president and ad interim president and chancellor for UNT (Bruton, 2006). Smith has served as a senior consultant to the American Association of State Colleges and Universities Resource Center for Planned Change in Washington, DC, and is nationally and internationally recognized for his con- 
tributions to both teacher education and higher education. He was cited at UNT for distinguished service to international education and since his retirement has served as chair of the Denton County Historical Commission, founded the board of the Texas Lakes Trail Region Inc., and served many years on the UNT College of Education Development Board (Bruton, 2006).

The instrument used in this study, the NDE Scale (Greyson, 1983, 1990), is a 16-item questionnaire devised to address cognitive, affective, paranormal, and transcendental components of an NDE. Each item addresses a particular NDE feature, and for each item a respondent indicates absence (0), presence (1), or strong presence (2) of the feature. According to Greyson a score of 7 out of a maximum possible score of 32 suggests an NDE (1983, p. 373). Using Cronbach's coefficient alpha to assess instrument reliability, Greyson found that "alpha for the entire NDE scale was .88; for Cognitive Component, .75; for Affective Component, .86; for the Paranormal Component, .66; and for the Transcendental Component, .76" (1983, p. 373). Greyson validated the scale through face and criterion validity (1983, p. 373). Since that time, numerous researchers have found similar psychometric results, and Lange, Greyson, and Houran (2004) utilized Rasch rating scale model to confirm the psychometric properties of the Scale.

For the interview, Holden and Smith met at the UNT Center for Media Production, where a videographer recorded their 31-minute interaction. Holden went into the interview with a set of open-ended questions about Smith's three experiences and about his comparison and contrasting of the tunnel-and-light feature among them. Interested readers may view the unabridged interview at https://vimeo .com/120078581 with password: journalpass.

\section{Results}

\section{Three Experiences}

Following are Smith's narratives about each of his experiences. For each one, we summarize circumstances and then provide in his own words the contents and, where relevant, aftereffects.

G-LOC. Regarding circumstance, Smith reported that as a young aviation cadet in the Air Force he experienced flying in high speed aircrafts. According to Whinnery (1997) "head-to-foot acceleration $(+\mathrm{Gz})$ stress is a unique aspect of flying fighter aircraft engaged in aerial combat maneuvering" (p. 232) that leads to rushing of blood 
to the extremities and eventually "cephalic nervous system ischemia" and G-LOC. Therefore, Smith was familiar with physiological consequences of high levels of g-force and, in particular, gun barrel vision. A medical dictionary definition of gun barrel vision or tunnel vision is "a constriction of the visual field, as though one were looking through a hollow cylinder or tube" (Tunnel vision, n.d.). Regarding content, Smith likened his gun barrel vision to looking down a "double barrel shot gun." He explained that in gun barrel vision "everything becomes focused," field of vision becomes narrow, "you lose your peripheral vision," and "everything becomes dimmer." Smith neither reported nor implied any aftereffects of his G-LOC experience.

NDE. Regarding circumstances, Smith indicated that his NDE occurred during an emergency visit to the hospital approximately 20 years prior to our interview. He reported that when he was admitted to the hospital he had lost a high volume of blood and was feeling faint due to what he later learned had been a rupture in his esophagus. Smith keenly pointed out that as he was lying on his back on the examining table of the emergency room he noticed the overhead lights on the ceiling. He described what happened next as going into shock, witnessing the light over his head becoming increasingly dimmer, and, after its disappearance, perceiving a bright light.

Regarding the contents of his NDE, Smith referred to it as being in a black void and witnessing a tunnel comprised of light. He characterized this light tunnel as a very bright white light that became focused-in the sense that everything else was black and he had no peripheral vision. He further reported that "I simply looked down the tunnel at the light, and when I came to I still had the memory of this light." He noted that although he did not recall the duration of time he spent in the tunnel, the memory of the tunnel was vivid for him after 20 years. Smith described the quality of tunnel of light as "nonthreatening," "warm," and welcoming. Furthermore, he recalled that as he looked down the tunnel of light, his affect was calm, content, peaceful, and positive. Smith claimed that during his NDE his consciousness continued in the domain of the light separate from his unconscious body that lacked cognitive activity or physical sensation. He did not recall regaining physical consciousness but, upon doing so, discovered that the nurse had moved his body to a sitting position while it was unconscious. Smith emphasized that he was not compelled to move forward in the tunnel of light.

Smith recounted several aftereffects of his NDE. He stated that 
his NDE enhanced and reinforced the reality of life after death and the continuation of consciousness. Consequently, Smith's NDE afforded him a lasting sense of peace regarding the process of dying. He equated the act of dying with "gently moving from one place to another."

Originally, Smith attempted to rationalize his experience of the tunnel of light. First, he disputed that the tunnel was the overhead lights that he witnessed in the emergency room because both his wife and nurse testified that, upon his loss of consciousness, the first and immediate step in his treatment was to move him from lying to sitting and to pull his head down between his legs. Therefore, Smith couldn't attribute the tunnel of light to the overhead light in the emergency room because at the time that he saw the tunnel of light he wasn't facing the ceiling. Next, Smith attempted to attribute the tunnel of light to physiological consequences of lack of oxygen to his brain due to his tremendous blood loss. He compared the quality of his NDE to his G-LOC experience noting that in G-LOC the tunnel was more defined whereas in his NDE the tunnel was diffused. Finally, Smith reconciled that his experience of the tunnel was unique and independent of his visual receptors and physiological changes in his body, and he began to treat it "matter of factly" as such.

ADC. In her systematic review of all research published on ADC through 2006, Jenny Streit-Horn (2011b) defined (ADC) as "a spontaneous phenomenon in which a living person has a feeling or sense of direct contact with a deceased person" (p. 1). She noted that ADCs can occur during wakefulness or sleep. Regarding the circumstances of Smith's ADC, he reported that not long after his wife passed away in 2004 he had a dream in which she appeared to him.

The contents of Smith's dream were that his wife, in her early twenties-much younger than when she had died, stood "about 40 yards down the tunnel but not in Technicolor; it looked like a construction paper silhouette cut out." He stated unequivocally that he did not have any doubts about the identity of his wife in that tunnel: He recognized the dress she was wearing as one she used to wear to work when they were first married; he held that his wife appeared in that familiar dress to communicate her identity to him. She also communicated her identity by the way she was standing which was "slightly turned to her right" - a stance that, based on a lifetime of marriage to her, implied to him: "Well, I'm waiting for you." Although Smith perceived his wife's anticipation, he was not compelled to move forward in the 
tunnel. Smith indicated that he typically does not retain the memory of his dreams and is only able to note if they were pleasant or unpleasant; by contrast, he recalled this dream vividly four years after he had it. This distinction between his ADC and his typical dreams mirrors a distinction most experiencers make: that compared to their usual dreams, the ADC felt real rather than dreamlike-a distinction that led Streit-Horn (2011a, 2011b) to refer to ADCs during sleep as "sleep ADCs" rather than "dream ADCs"-to more accurately describe the circumstances in a way that honors the distinction that experiencers usually make-often emphatically.

Smith reported one aftereffect of his sleep ADC to be the perception that his wife remains in anticipation of their reunion. Other aftereffects included reassurance that consciousness continues after death, an increased sense of spirituality which he distinguished from religiosity, and openness to experiences that are not rationally justified. He expanded on his definition of spirituality in stating that his sleep ADC reinforced for him "that there is a continuum here and in that continuum we maintain some sense of identity."

\section{Comparisons}

NDE Scale scores provided data for quantitative comparison of the experiences. Although we asked Smith to complete the Scale only on his NDE, he took the initiative also to provide a second column of responses with reference to his ADC. We subsequently realized that although the NDE Scale was developed to assess only NDEs, Smith had provided us a means to compare-albeit in a preliminary and unofficial way-all three of his experiences through Scale scores. Consequently, we later asked him also to complete the Scale with reference to his G-LOC experiences. Results are summarized in Table 1.

Further comparisons arose in or from Smith's narrative. Beginning with a comparison of the light in his NDE and his ADC, Smith noted two similarities. First, he stated that the subjective quality of the two lights was the same. Second, he indicated that in both experiences he "did not feel any need or compulsion to move forward into the light."

Regarding a comparison of the light across all three experiences, he noted one similarity: "You minimalize any breadth of vision; everything becomes focused. And in both instances they are focused. Gun barrel [in G-LOC] is kind of a straight ahead sort of thing, and you lose your peripheral vision, and the tunnel light [in NDE and ADC] is everything else is black out; there's no vision there. In that sense, 
Table 1 Comparison of Near-Death Experience Scale Responses for Three Experiences

\begin{tabular}{|c|c|c|c|}
\hline & G-LOC & NDE & ADC \\
\hline $\begin{array}{l}\text { 1. Did time seem to speed up or slow down? } \\
\begin{array}{cl}0 & \text { No. } \\
1 & \text { Time seemed to go faster or slower than usual. } \\
2 & \text { Everything seemed to be happening at once; or time } \\
\text { stopped or lost all meaning. }\end{array}\end{array}$ & 0 & 0 & 0 \\
\hline $\begin{array}{l}\text { 2. Were your thoughts speeded up? } \\
\begin{array}{ll}0 & \text { No. } \\
1 & \text { Faster than usual. } \\
2 & \text { Incredibly fast. }\end{array}\end{array}$ & 0 & 0 & 0 \\
\hline $\begin{array}{l}\text { 3. Did scenes from your past come back to you? } \\
\begin{array}{ll}0 & \text { No. } \\
1 & \text { I remember many past events. } \\
2 & \text { My past flashed before me, out of my control. }\end{array}\end{array}$ & 0 & 0 & 0 \\
\hline $\begin{array}{l}\text { 4. Did you suddenly seem to understand everything? } \\
\qquad \begin{array}{ll}0 & \text { No. } \\
1 & \text { Everything about myself or others. } \\
2 & \text { Everything about the universe. }\end{array}\end{array}$ & 0 & 0 & 1 \\
\hline $\begin{array}{l}\text { 5. Did you have a feeling of peace or pleasantness? } \\
\begin{array}{ll}0 & \text { No. } \\
1 & \text { Relief or calmness. } \\
2 & \text { Incredible peace or pleasantness. } \\
\end{array}\end{array}$ & 1 & 1 & 2 \\
\hline $\begin{array}{l}\text { 6. Did you have a feeling of joy? } \\
\begin{array}{ll}0 & \text { No. } \\
1 & \text { Happiness. } \\
2 & \text { Incredible joy. }\end{array}\end{array}$ & 0 & 1 & 2 \\
\hline $\begin{array}{l}\text { 7. Did you feel a sense of harmony or unity with the } \\
\text { universe? } \\
0 \text { No. } \\
1 \text { I felt no longer in conflict with nature. } \\
2 \text { I felt united or one with the world. }\end{array}$ & 0 & 2 & 2 \\
\hline $\begin{array}{l}\text { 8. Did you see, or feel surrounded by, a brilliant light? } \\
0 \text { No. } \\
1 \text { An unusually bright light. } \\
2 \text { A light clearly of mystical or other-worldly origin. }\end{array}$ & 1 & 1 & 1 \\
\hline
\end{tabular}




\begin{tabular}{|c|c|c|c|}
\hline & G-LOC & NDE & ADC \\
\hline $\begin{array}{l}\text { 9. Were your senses more vivid than usual? } \\
\begin{array}{ll}0 & \text { No. } \\
1 & \text { More vivid than usual. } \\
2 & \text { Incredibly more vivid. }\end{array}\end{array}$ & 1 & 0 & 0 \\
\hline $\begin{array}{l}\text { 10. Did you seem to be aware of things going on elsewhere, } \\
\text { as if by ESP? } \\
0 \text { No. } \\
1 \text { Yes, but the facts have not been checked out. } \\
2 \text { Yes, and the facts have been checked out. }\end{array}$ & 0 & 0 & 0 \\
\hline $\begin{array}{l}\text { 11. Did scenes from the future come to you? } \\
\begin{aligned} 0 & \text { No. } \\
1 & \text { Scenes from my personal future. } \\
2 & \text { Scenes from the world's future. }\end{aligned}\end{array}$ & 0 & 0 & 1 \\
\hline $\begin{array}{l}\text { 12. Did you feel separated from your body? } \\
\begin{aligned} 0 & \text { No. } \\
1 & \text { I lost awareness of my body. } \\
2 & \text { I clearly left my body and existed outside it. }\end{aligned}\end{array}$ & 1 & 1 & 1 \\
\hline $\begin{array}{l}\text { 13. Did you seem to enter some other, unearthly world? } \\
\begin{array}{l}0 \text { No. } \\
1 \text { Some unfamiliar and strange place. } \\
2 \text { A clearly mystical or unearthly realm. }\end{array}\end{array}$ & 0 & 2 & 2 \\
\hline $\begin{array}{l}\text { 14. Did you seem to encounter a mystical being or } \\
\text { presence, or hear an unidentifiable voice? } \\
0 \text { No. } \\
1 \text { I heard a voice I could not identify. } \\
2 \text { I encountered a definite being, or a voice clearly of } \\
\text { mystical or unearthly origin. }\end{array}$ & 0 & 0 & 2 \\
\hline $\begin{array}{l}\text { 15. Did you see deceased or religious spirits? } \\
\begin{array}{ll}0 & \text { No. } \\
1 & \text { I sensed their presence. } \\
2 & \text { I actually saw them. }\end{array}\end{array}$ & 0 & 0 & 2 \\
\hline $\begin{array}{l}\text { 16. Did you come to a border or point of no return? } \\
0 \text { No. } \\
1 \text { I came to a definite conscious decision to return to } \\
\text { life. } \\
2 \text { I came to a barrier that I was not permitted to cross; } \\
\text { or was sent back against my will. }\end{array}$ & 0 & 0 & 0 \\
\hline $\begin{array}{rr} & \text { Total } \\
\end{array}$ & 4 & 8 & 16 \\
\hline
\end{tabular}

Note. In NDE assessment, total score of 7 or above indicates an NDE; instrument not designed or previously used to assess G-LOC or ADC. 
there is a similarity." Thus, in all cases he perceived darkness in his outer visual field and light in the center of it. He also noted a difference regarding brightness and changes in brightness: "It seems like to me that when you have gun barrel vision [in G-LOC] it tends to all get dimmer, not brighter. Whereas this experience [NDE and ADC] it's brighter rather than dimmer." One further difference in the appearance of the tunnel across the three experiences comes from Whinnery's (1997) reference to "coming out of the darkness of a tunnel" in the G-LOC experience. By contrast, Smith conveyed that in his NDE and ADC the light "was a tunnel of light in a black expanse." Thus, Smith and Whinnery agree that in G-LOC, the tunnel dims and goes dark, whereas in Smith's NDE and ADC, the tunnel was and remained exceptionally bright: "I'd call it a white light. I don't know how better to describe it other than that. It wasn't a search light type, it didn't stay that focused, it diffused gradually rather than a hard line around it but whitish I'd say and very bright, very bright."

Another difference involved an affective quality of the tunnel in the experiences. Although he did not report any affective quality to the tunnel vision of his G-LOC experience he described the quality of the tunnel of light in his NDE as "welcoming" and in his ADC as very "reassuring."

Another domain of comparison is the quality of recall of the experiences. When Holden asked Smith about the details of his G-LOC experiences, he replied, "I don't recall very well." However, he emphasized that he vividly recalled the tunnel of light in both his NDE and ADC. By contrast with his sleep ADC, he stated that he generally is "not able to reproduce"- that is, recall, his dreams. By contrast with his NDE, he reported, "there have been one or two medical occasions where I have been able to reproduce some circumstances during my recovery but not as vividly as I did the light." He noted the exceptional quality whereby he found that his recall of both his NDE and ADC did not degrade over time: "Both the light and the dream: They're fixed in my mind, and they don't change, they don't alter with time; they are just like they were the first time I experienced them." Thus, although he was unable to clearly recall his G-LOC experiences that had occurred more than once, and could not usually recall dreams that, according to research, occur nightly, he vividly recalled his singular NDE and ADC experiences without alteration or degradation.

A final domain of comparison is aftereffects of the experiences. Though he reported no emotional quality during his G-LOC experience nor emotional residue following it, he stated with reference to his NDE that "I came away with the greatest sensation." 
Similarly, although Smith did not mention any changes in his spirituality or understanding of afterlife after his G-LOC experiences he noted that his NDE "reinforced" and clarified his understanding of afterlife and that his sleep ADC increased his sense of spirituality. He stated that his takeaway from his NDE and ADC is that death is like "moving from one thing to another" and, in a sense, it is a continuation of, or on a continuum with, physical existence whereby in death "we maintain some sense of identity."

In summary, in comparing the qualities of his NDE and his ADC, Smith found no differences and several similarities, whereas in comparing the qualities of his G-LOC experiences on the one hand and his two transpersonal experience on the other, he found one similarity and several differences. Whereas he found the transpersonal experiences to be qualitatively similar, he found the G-LOC experience to be qualitatively different than the transpersonal experiences. A summary of the comparisons appears in Table 2.

\section{Discussion}

Tunnels and light are common features of NDEs, and tunnel vision is often reported by individuals who experience high gravitational force, such as pilots. To date, comparisons of these experiences have involved descriptions by people who had had one or the other experience, but not both experiences. In this case study, we drew from the NDE Scale results and an interview of one individual who had had both experiences as well as an ADC with tunnel and light features, placing him in a unique position to compare the experiences overall and the specific features in particular.

Smith, with a distinguished career in higher education and ongoing civic engagement since his retirement from it, appeared to be a credible source with no apparent ulterior motive to misrepresent his experiences. Regarding his NDE Scale results, the total score for his NDE was 8, exceeding the criterion of 7 to indicate the likely presence of an NDE. Interestingly, the score for his assessment of his ADC was even higher: 16. Although the NDE Scale was not designed and has not been used in ADC research, the strength of the score indicates that the experience involved features known in the field of near-death studies to be associated with personal meaning and transformative aftereffects-which corresponds to Smith's narrative regarding the experience. Interestingly, the G-LOC score of 4 did not meet the 
Table 2 Similarities and Differences Between Subjectively Reported Qualities of Three Experiences*

\begin{tabular}{|c|c|c|c|}
\hline Characteristic & G-LOC & NDE & ADC \\
\hline \multirow[t]{2}{*}{ Circumstances } & \multicolumn{3}{|c|}{ Altered state of consciousness occurring during } \\
\hline & Gravitational force & Medical condition & Sleep \\
\hline Field of vision & \multicolumn{3}{|c|}{$\begin{array}{c}\text { "Breadth of vision is minimalized and everything becomes focused." } \\
\text { Light center; dark periphery: } \\
\text { "Peripheral vision is out." "Everything but the light is blacked out." }\end{array}$} \\
\hline $\begin{array}{l}\text { Overall appear- } \\
\text { ance and felt } \\
\text { sense of tunnel } \\
\text { and light }\end{array}$ & $\begin{array}{l}\text { Different from other } \\
\text { two experiences }\end{array}$ & \multicolumn{2}{|c|}{ Same between these two experiences } \\
\hline $\begin{array}{l}\text { Light: } \\
\text { Brightness }\end{array}$ & $\begin{array}{l}\text { During experience, } \\
\text { lost brightness/ } \\
\text { became dimmer }\end{array}$ & $\begin{array}{l}\text { Hospital overhead } \\
\text { lights dimmed and dis- } \\
\text { appeared, then bright } \\
\text { light appeared that } \\
\text { remained bright }\end{array}$ & $\begin{array}{l}\text { Bright light that re- } \\
\text { mained consistently } \\
\text { bright }\end{array}$ \\
\hline Light: Color & None reported & \multicolumn{2}{|l|}{ White } \\
\hline Light: Sharpness & $\begin{array}{l}\text { "Focused with a } \\
\text { hard line around it" }\end{array}$ & \multicolumn{2}{|c|}{$\begin{array}{l}\text { "It didn't stay that focused; it diffused gradu- } \\
\text { ally rather than a hard line around it" }\end{array}$} \\
\hline Light: Affective & None reported & $\begin{array}{l}\text { "Non-threatening," } \\
\text { "warm," "welcoming" }\end{array}$ & "Reassuring" \\
\hline Impetus to move & None reported & \multicolumn{2}{|c|}{$\begin{array}{l}\text { "I did not feel any need or compulsion to } \\
\text { move forward into the light." }\end{array}$} \\
\hline $\begin{array}{l}\text { Afterwards: } \\
\text { Memory } \\
\text { retention }\end{array}$ & $\begin{array}{l}\text { "I don’t recall very } \\
\text { well." }\end{array}$ & $\begin{array}{l}\text { "I still can see it right } \\
\text { now } 20 \text { years later very } \\
\text { clearly. I still have that } \\
\text { central vision of it." } \\
\text { "Fixed in my mind." } \\
\text { "Vivid." Does not "alter } \\
\text { with time." }\end{array}$ & $\begin{array}{l}\text { "Retained memory } \\
\text { of light after } 4 \text { years } \\
\text { and I still retain } \\
\text { that vision and } \\
\text { I don't [usually] } \\
\text { retain visions of my } \\
\text { dreams." }\end{array}$ \\
\hline $\begin{array}{l}\text { Afterwards: } \\
\text { Spirituality }\end{array}$ & None reported & \multicolumn{2}{|c|}{$\begin{array}{l}\text { Greater spirituality, as opposed to religion; } \\
\text { greater openness to experiences that cannot } \\
\text { be explained rationally. }\end{array}$} \\
\hline $\begin{array}{l}\text { Afterwards: } \\
\text { Afterlife beliefs }\end{array}$ & None reported & $\begin{array}{l}\text { "Reinforced" and clari- } \\
\text { fied "life after death;" } \\
\text { "moving from one } \\
\text { thing to another" }\end{array}$ & $\begin{array}{l}\text { "Tends to reinforce } \\
\text { for me that there } \\
\text { is a continuum } \\
\text { here and that in } \\
\text { that continuum } \\
\text { we maintain some } \\
\text { sense of identity." }\end{array}$ \\
\hline
\end{tabular}

Note. *Similarities presented in italics; differences presented in regular font. 
criterion of 7-which also corresponded to Smith's assertion that the experience held no personal meaning and resulted in no aftereffects.

Regarding the qualitative data, during the interview Smith described several features and aftereffect of G-LOC, NDE, and ADC that corresponded to those features and aftereffects as described in other comprehensive sources on these topics (Holden, Greyson, \& James, 2009; Streit-Horn, 2011a, 2011b; Whinnery, 1990, 1997); in fact we found no features that did not correspond. This congruence contributed to the reliability of Smith's report. However, we believe two features deserve more detailed discussion.

One feature is the illuminative characteristic of the tunnel in Smith's experiences. In Kevin Drab's (1981) comparison of 71 tunnel experiences in NDEs, the $55 \%$ of descriptions that provided information about the feature of illumination consisted of $45 \%$ "dark, black" tunnels, 4\% "dimly lit" tunnels, and 6\% "brightly lit" tunnels (p. 133). Thus, Smith's tunnel, belonging to the latter category, was not characteristic of most NDE tunnels, though he was not alone in the experience of a brightly lit tunnel.

The other feature is the quality of comparative memory between his three experiences. Poorer memory of his G-LOC experiences could be attributed to their having occurred in the more distant past and/or to the research finding that combat-related experiences are repressed more than are other experiences (Schooler \& Eich, 2000; Southwick, Morgan, Nicolaou, \& Charney, 1997). These possibilities, however, are contradicted by Smith's own assessment that his less vivid memory of multiple G-LOC experiences compared to his memories of his single near-death and ADC experiences were the result of the lesser psychospiritual impact of the former experiences.

After analysis of the quantitative and qualitative results, and considering the consistency between them, we concluded that all three experiences shared two similarities: All occurred in an altered state of consciousness and involved a visual field consisting of a light center and dark periphery. We also found that the NDE and ADC were predominantly similar to each other with regard to nine features of contents and aftereffects-and differed from G-LOC with regard to those same nine features. Our conclusion was to agree with Smith in his assertion that, in general, the NDE and ADC were substantially different from the G-LOC experience, and specifically, the tunnel-andlight feature in his NDE and ADC was different from that feature in the G-LOC he experienced as an aviation cadet. 
These findings indicate a difference between the qualia of experiences known to result from hypoxia and anoxia, such as G-LOC, and the qualia of experiences in the transpersonal domain. These findings further challenge the materialist theory that specific features such as a tunnel and light can be reduced to physiological causes such as reduced oxygen to the brain.

An obvious limitation of this and all case studies is small sample size. Future researchers may seek to find additional individuals like Smith who have a history of both G-LOC and NDE-but such individuals may be difficult to find. A brief online search revealed that G-LOC experiences are limited to pilots—and pilots with both experiences in their histories may be rare; Smith was certainly the only one Holden had encountered in 30 years of NDE research.

Another approach is to conduct intervention research. For example, one possible protocol would involve three groups of volunteers who have never experienced G-LOC: survivors of a close brush with death with an NDE, survivors of a close brush with death without an NDE, and people who do not recall ever having come close to death. With participants in the first two groups using their close brush with death and participants in the third group using some other historical marker such as their most frightening life experience as a referent, all participants would complete the NDE Scale and an interview about the experience and its aftereffects, both to confirm their status in the group-NDErs scoring 7 or higher on the NDE Scale and describing established NDE contents and aftereffects, and non-NDErs scoring 6 or lower with corresponding narratives-and as a basis for comparison with G-LOC. All participants would then experience G-LOC through a procedure to induce cerebral hypoxia from extreme acceleration resulting in excessive g-forces. Upon completion, and again at follow-up one or more months later, all participants would again complete the NDE Scale and an interview with regard to the G-LOC experience. The inclusion of comparison groups 2 and 3 would enable researchers to investigate whether NDErs' G-LOC experiences differ from others'. If they don't-and if the results show a significant difference between NDEs and G-LOC experiences, our preliminary findings in this case study would be supported. It is our hope that future researchers will undertake these and/or related studies to further clarify the relative adequacy of materialist, reductionist explanations versus other types of explanations for NDEs and other transpersonal experiences. 


\section{References}

Agrillo, C. (2011). Near-death experience: Out-of-body and out-of-brain? Review of General Psychology, 15(1), 1-10. doi:10.1037/a0021992

American Heart Association. (2014, October 23). Syncope (fainting). Retrieved from http://www.heart.org/HEARTORG/Conditions/Arrhythmia/SymptomsDiagnosisMonitoringofArrhythmia/Syncope-Fainting_UCM_430006_Article .jsp\#.VqZk2_krKUk

Blackmore, S.J. (1996). Near-death experiences. Journal of the Royal Society of Medicine, 89, 73-76.

Broome, K. (Producer). (2002). The day I died: The mind, the brain, and neardeath experiences [Motion picture]. Glasgow, Scotland: British Broadcasting Corporation.

Bruton, C. (2006). A career beyond measure [The North Texan online]. Retrieved from http://www.unt.edu/northtexan/archives/w06/careerbeyondmeasure.htm

Drab, K. (1981). The tunnel experience: Reality or hallucination? AnabiosisThe Journal for Near-Death Studies, 1(2), 126-152.

Federal Aviation Administration. (2004). Hypoxia [Brochure]. Retrieved from http://www.faa.gov/pilots/safety/pilotsafetybrochures/media/hypoxia.pdf

Greyson, B. (1983). The Near-Death Experience Scale: Construction, reliability, and validity. Journal of Nervous and Mental Disease, 171(6), 369-375.

Greyson, B. (1990). Near-death encounters with and without near-death experiences: comparative NDE Scale profiles. Journal of Near-Death Studies, 8(3), $151-161$.

Greyson, B., Kelly, E. W., \& Kelly, E. F. (2009). Explanatory models for near-death experiences. In J.M. Holden, B. Greyson, \& D. James (Eds.), The handbook of near-death experiences: Thirty years of investigation (pp. 213-234). Santa Barbara, CA: Praeger/ABC-CLIO.

Holden, J.M., Greyson, B., \& James, D. (Eds.). (2009). The handbook of neardeath experiences: Thirty years of investigation. Santa Barbara, CA: Praeger.

Kelly, E.F., Kelly, E.W., Crabtree, A., Gauld, A., Grosso, M., \& Greyson, B. (2007). Irreducible mind: Toward a psychology for the 21st century. Lanham, MA: Rowman \& Littlefield.

Lange, R., Greyson, B., \& Houran, J. (2004). A Rasch scaling validation of a 'core' near-death experience. British Journal of Psychology, 95, 161-77.

Lempert, T., Bauer, M., \& Schmidt, D. (1994). Syncope and near-death experience. The Lancet, 344(8925), 829.

Moody, R.A. (1975). Life after life. Atlanta, GA: Mockingbird Books.

Schooler, J.W., \& Eich, E. (2000). Memory for emotional events. In E. Tulving \& F.I.M. Craik (Eds.), The Oxford handbook of memory (pp. 379-392). Oxford, England, UK: Oxford University Press.

Southwick, S. M., Morgan, C.A., Nicolaou, A. L., \& Charney, D. S. (1997). Consistency of memory for combat-related traumatic events in veterans of Operation Desert Storm. American Journal of Psychiatry, 154, 173-177.

Streit-Horn, J. (2011b). Fact sheet: After-death communication. Retrieved from http://www.coe.unt.edu/sites/default/files/22/129/ADC.pdf

Taka, J. (2010, May 30). The day I died - NDE documentary Part 2 of 6 [Video file]. Retrieved from https://www.youtube.com/watch?v=xsvkJeX5OE0 
Tunnel vision. (n.d.). In Farlex Partner Medical Dictionary. (2012). Retrieved from http://medical-dictionary.thefreedictionary.com/tunnel+vision

Whinnery, J. E. (1990). The G-LOC syndrome (NADC Technical Report No. 9104260). Warminster, PA: Naval Air Development Center.

Whinnery, J.E. (1997). Psychophysiologic correlates of unconsciousness and near-death experiences. Journal of Near-Death Studies, 15(4), 231-258.

Wright, M. (2008, Winter). Out of your mind. TCU Magazine. Retrieved from http://www.magarchive.tcu.edu/articles/2008-01-AN2.asp

Zingrone, N.L., \& Alvarado, C.S. (2009). Pleasurable Western adult near-death experiences: Features, circumstances, and incidence. In J. M. Holden, B. Greyson, \& D. James (Eds.), The handbook of near-death experiences: Thirty years of investigation (pp. 17-40). Santa Barbara, CA: Praeger/ABC-CLIO. 